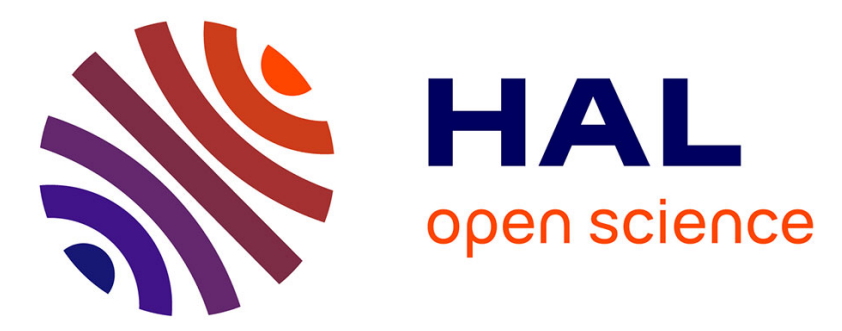

\title{
New porous bismuth electrode material with high surface area
}

\author{
R. Abdallah, A. Derghane, Y.-Y. Lou, O. Merdrignac-Conanec, D. Floner, F.
} Geneste

\section{- To cite this version:}

R. Abdallah, A. Derghane, Y.-Y. Lou, O. Merdrignac-Conanec, D. Floner, et al.. New porous bismuth electrode material with high surface area. Journal of Electroanalytical Chemistry, 2019, 839, pp.32-38. 10.1016/j.jelechem.2019.03.023 . hal-02090007

\section{HAL Id: hal-02090007 https://hal-univ-rennes1.archives-ouvertes.fr/hal-02090007}

Submitted on 2 Jul 2019

HAL is a multi-disciplinary open access archive for the deposit and dissemination of scientific research documents, whether they are published or not. The documents may come from teaching and research institutions in France or abroad, or from public or private research centers.
L'archive ouverte pluridisciplinaire HAL, est destinée au dépôt et à la diffusion de documents scientifiques de niveau recherche, publiés ou non, émanant des établissements d'enseignement et de recherche français ou étrangers, des laboratoires publics ou privés. 
New porous bismuth electrode material with high surface area

Rawa Abdallah ${ }^{\mathrm{a}, \mathrm{b}}$, Adib Derghane ${ }^{\mathrm{a}}$, Yao-Yin Lou ${ }^{\mathrm{a}}$, Odile Merdrignac-Conanec ${ }^{\mathrm{a}}$, Didier Floner ${ }^{\mathrm{a} *}$, Florence Geneste ${ }^{a^{*}}$,

${ }^{a}$ Univ Rennes, CNRS, ISCR-UMR 6226, F-35000 Rennes, France

${ }^{b}$ Université Libanaise, EDST, Centre Azm pour la Recherche en Biotechnologie et ses Applications, Laboratoire des Biotechnologie appliquées, Rue El Mitein, Tripoli, Lebanon

\begin{abstract}
Bismuth electrodes are particularly interesting owing to their high hydrogen evolution overpotential and electrocatalytic activity. In this work, a novel porous bismuth electrode was prepared via an electrochemical deposition of bismuth on a porous graphite felt of high specific surface area, employing bismuth(III) oxide as reactant and a flow electrochemical cell as reactor. A solubility up to $1 \mathrm{~mol} \mathrm{~L}^{-1}$ of bismuth was obtained in basic medium using a suitable complexing agent. We solved the problems linked to the heterogeneous potential distribution in the $3 \mathrm{D}$ porous structure and to the formation of dendritic excrescences that led to mechanically fragile material by using a suitable flow electrochemical cell, a periodically changing current with short on-pulses and long off-pulses and by limiting the electrodeposition of $\mathrm{Bi}$ on the external surfaces of the felt due to diffusion. A Bi-modified electrode with high specific surface area and low bulk density was achieved using this method.
\end{abstract}

Keywords. Bismuth; electrodeposition; 3D porous electrode; Felt; Flow cell; Homogenous coating

\title{
1. Introduction
}

In recent years, bismuth-film electrodes (BFEs) have become an interesting topic for the electrochemical community due to the unique electrical and physicochemical properties of bismuth $[1,2]$. One of the most attractive properties of this cost-effective material is its high hydrogen evolution overpotential $[3,4]$. Bismuth (Bi) is also an environmentally friendly element with a very low toxicity in terms of final disposal of laboratorial effluents [5,6] and thus is extremely attractive for a wide range of environmental, clinical and industrial applications [7].

Ten years ago, BFEs were suggested as one of the best replacement materials for mercury-film electrodes. Such materials are in high demand for the cathodic detection of pollutants such as drugs [8], pesticides [9,10] metallic ions [11,12] and have also been used as anticorrosive coatings

${ }^{*}$ Corresponding authors.

E-mail addresses: Didier.floner@univ-rennes1.fr (D. Floner), Florence.geneste@ univ-rennes1.fr (F. Geneste). 
$[13,14]$. More recently, the high electrocatalytic activity of bismuth for $\mathrm{CO}_{2}$ reduction has attracted a lot of attention [15-17]. It highly promotes the formation of $\mathrm{CO}$ or formate depending on the nature of the electrolytic medium. It has also been successfully used as electrode material in redox flow battery to improve charge-transfer rate between the electrode and electrolyte interface owing to its better electrical conductivity than carbon and to prevent the irreversible hydrogen evolution [18].

In general, BFEs can be prepared by many methods, such as electrodeposition [19], thermal evaporation [20], molecular beam epitaxy [21], direct current sputtering [22] and radio frequency magnetron sputtering [23]. Among these methods, electrochemical deposition is a simple route to control the surface morphology of the deposits by changing some parameters of the electroplating solutions such as the complexing agents, the composition, the $\mathrm{pH}$, the additives, and the temperature, as well as the deposition conditions e.g., the applied potential and the current density [24,25]. Moreover, it holds other advantages including a mass productivity, a high deposition rate, a cost-effectivity and an industrially well-established technology.

The electrodeposition of bis muth on different supports has been widely studied. Much of the studies have focused either on its nucleation and growth onto non-metallic substrates or its underpotential deposition (upd) onto noble metals [1]. In most cases, a carbon substrate is used to support the bismuth film including, carbon paste [26,27], wax-impregnated graphite [28], glassy carbon [28-30], screen-printed carbon ink [31] and pencil-lead [32]. Porous bismuth materials have also been investigated owing to their interesting high surface area/volume ratio that enhances interactions with compounds in solution. Thus nanostructured bis muth porous electrodes have been prepared by fast electroreduction of the $\mathrm{Bi}^{3+}$ ions [33,34] or by electrodeposition on a network of polystyrene nanoparticules that after dissolution gave pores within the metal film [12].

Carbon felts have a porous structure with a high specific surface area ranging from 0.7 to $2000 \mathrm{~m}^{2} \mathrm{~g}^{-}$ ${ }^{1}$, resulting in a low cost and a good availability of the material. Therefore, they can be considered as good starting materials to prepare porous three-dimensional (3D) bismuth electrodes. Bismuth electroplating on solid electrodes is the most widely used electrodepositing process. However, the extension to $3 \mathrm{D}$ structures is more challenging since the potential distribution is not homogeneous and it decreases from the exterior surface toward the interior of the material [35]. Therefore, metal electrodeposition takes place mainly on the surface and hardly penetrates into the material [36]. They are only a few studies which investigate the electroplating of metals on graphite felts [36-38]. To our knowledge, no study has been focused until now on the electrodeposition of bismuth on carbon felts. In this work, we report a suitable electrodeposition method to homogeneously coat fibers of graphite felts by bismuth. We first determined the best conditions to solubilize $\mathrm{Bi}_{2} \mathrm{O}_{3}$ in aqueous solutions and then tune the electrodeposition parameters to obtain a homogeneous and 
mechanically stable coating of $\mathrm{Bi}$ on the graphite felt electrode. The electrode material was characterized by SEM imaging and BET measurements.

\section{Experimental section}

\subsection{Materials}

Graphite felt (RVG 4000) used as Bi electroplating support was obtained from Mersen (Paris La Defense, France). Its specific area, measured by the BET method is $0.7 \mathrm{~m}^{2} \mathrm{~g}^{-1}$, its carbon yield is $99.9 \%$ and its bulk density is $0.088 \mathrm{~g} \mathrm{~cm}^{-3}$. All chemicals used for the preparation of stock and standard solutions were supplied by Sigma-Aldrich.

\subsection{Electrochemical analysis}

All experiments were performed at room temperature. Electrochemical analyses of different $\mathrm{Bi}(\mathrm{III})$ solutions were carried out using a conventional three-electrodes cell with a glassy carbon electrode (GCEs, $7 \mathrm{~mm}^{2}$ ) as working electrode. Saturated calomel electrode and a platinum wire were used as reference and auxiliary electrodes, respectively. Voltammetry analyses were performed using a Biologic sp-150 potentiostat (Claix, France). Before analysis, $\mathrm{N}_{2}$ gas bubbling was conducted for $5 \mathrm{~min}$ to remove dissolved oxygen in the electrolyte.

\subsection{Electrodeposition of $\mathrm{Bi}$}

Bi electrodeposition was realized under pulsed current conditions using a home-made flow electrochemical cell (Figure 1).

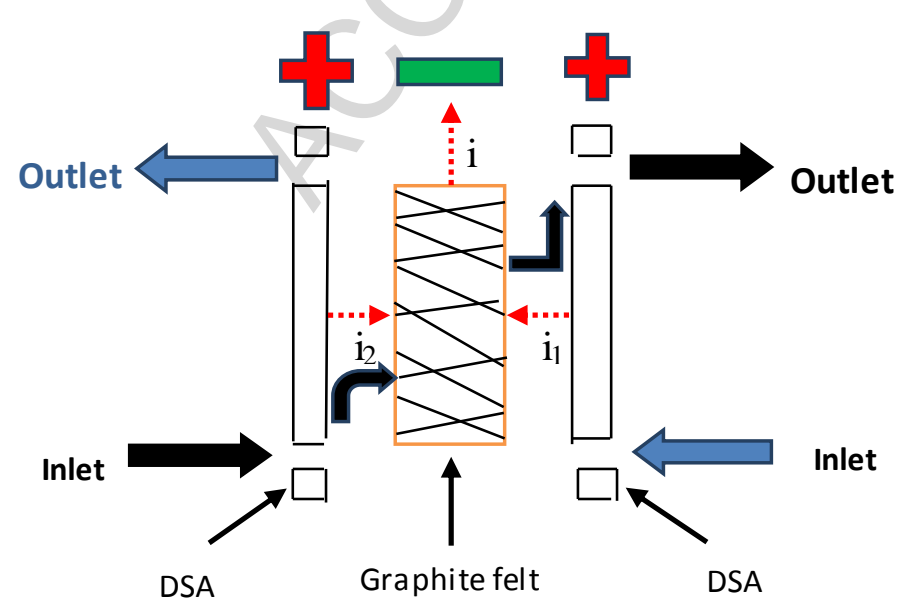

Fig. 1. Scheme of the electrochemical flow cell used for bismuth electroplating. $i_{1}+i_{2}=i$ 
$2 \mathrm{~L}$ of electrolytic solution were prepared adding $10 \mathrm{~mL}$ of a solution of $0.5 \mathrm{~mol} \mathrm{~L} \mathrm{Bi}_{2} \mathrm{O}_{3}+$ $1.1 \mathrm{~mol} \mathrm{~L}^{-1} 2,2-\mathrm{Bis}($ hydroxymethyl)-2,2',2''-nitrilotriethanol adjusted to $\mathrm{pH} 14$, to a solution of 0.1 mol L ${ }^{-1} \mathrm{NaOH}$ and $0.25 \mathrm{~mol} \mathrm{~L}{ }^{-1} \mathrm{Na}_{2} \mathrm{SO}_{4}$. The Bi solution flowed through the working electrode (graphite felt cuboid : $11 \times 6 \mathrm{~cm}, 3 \mathrm{~mm}$ thickness, weight $1.74 \mathrm{~g}$ ) perpendicular to its surface. To improve the homogeneity of the potential distribution in the $3 \mathrm{D}$ working electrode, the felt was located between two counter-electrodes (dimensionally stable anodes: DSA) [39]. Several cycles corresponding to a pass through the graphite felt in one direction and another pass in the opposite direction were performed to assure a good coating of the felt. The electrical contact with the working electrode was performed with platinum grids. A periodically changing current (on-pulse: 5 A, off-pulse: 0 A) was applied between the electrodes, using a Power Flex generator. The flow rate $\left(50 \mathrm{~mL} \mathrm{~min}^{-1}\right)$ of the electrolytic solution was monitored by a Gilson minipuls 2 peristaltic pump (Middleton, WI, USA). After each pass of the solution through the electrode, the concentration of $\mathrm{Bi}$ and $\mathrm{pH}$ were adjusted at $5 \times 10^{-3} \mathrm{~mol} \mathrm{~L}^{-1}$ using a solution of $1 \mathrm{~mol} \mathrm{~L}^{-1}$ of Bi(III) and at pH 13-14 using a concentrated solution of $\mathrm{NaOH}$, respectively. The concentration of bismuth in the solution was measured thanks to linear sweep voltammetry on a rotating disk electrode (Figure 2).

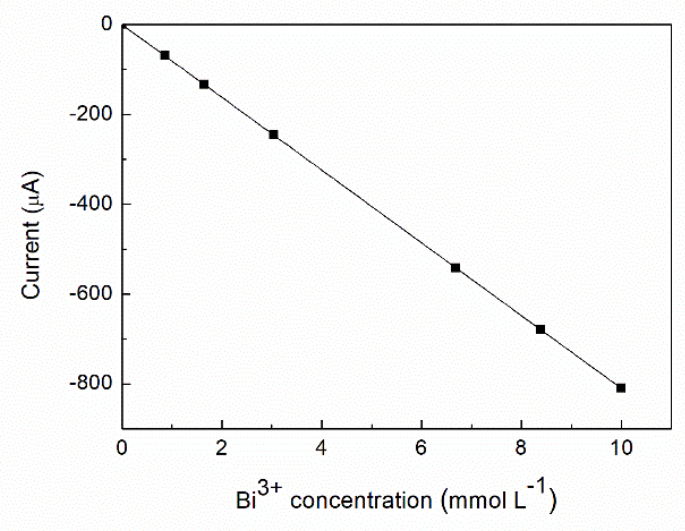

Fig. 2. Current versus Bi(III) concentration obtained by linear sweep voltammetry on rotating disk electrode (glassy carbon) in solutions of Bis-Tris at $\mathrm{pH} 13$ at $1500 \mathrm{rpm}$ and $5 \mathrm{mV} \mathrm{s}^{-1}$.

\subsection{Apparatus}

The SEM (scanning electron microscope) micrographs were obtained with a Jeol JSM $7100 \mathrm{~F}(10 \mathrm{kV})$ instrument, equipped with a field emission gun, operating in high vacuum conditions, at an accelerating voltage variable from 2 to $20 \mathrm{keV}$, depending on the observation needs. A pH-meter (HI 2210 pH meter, Hanna instruments) in combination with a $\mathrm{Ag} / \mathrm{AgCl}$ (3.0 mol $\mathrm{L}^{-1} \mathrm{KCl}$ ) glass electrode was used to check the $\mathrm{pH}$ of the electrolyte solutions. 


\subsection{Nitrogen adsorption isotherms}

Nitrogen adsorption isotherms were recorded at liquid nitrogen temperature $(77 \mathrm{~K})$ using a Micromeritics Gemini VII Surface Area and Porosity Analyzer. Prior to adsorption, the electrode materials were outgassed overnight under vacuum at room temperature to remove all physisorbed material. Specific surface areas (SSA) were calculated by Brunauer-Emmett-Teller (BET) method from $\mathrm{N}_{2}$ adsorption data in the relative pressure range $0.05-0.25$.

\section{Results and discussion}

\subsection{Solubilization of Bismuth}

The electrodeposition of metals on plane surfaces usually requires a high concentration of metal ions and a low applied current density to allow the diffusion of the cations to the electrode surface during the electrochemical process. $\mathrm{Bi}^{3+}$ ion gives bismuth hydroxide that precipitates in neutral and alkaline media according to the following reaction $\left(\mathrm{Ks}=10^{-30.75}\right)$ :

$$
\mathrm{Bi}^{3+}+3 \mathrm{OH}^{-} \longrightarrow \mathrm{Bi}(\mathrm{OH})_{3}
$$

For example, a $\mathrm{pH}$ lower than 4 is required to obtain $\mathrm{Bi}^{3+}$ ions at a concentration of $0.1 \mathrm{~mol} \mathrm{~L}^{-1}$. Owing to the low solubility of bismuth, many efforts have been made to find the best conditions to solubilize it [33]. Since bismuth gives insoluble species in neutral and basic medium, we first studied their solubility in acidic medium (Table 1). $\mathrm{Bi}_{2} \mathrm{O}_{3}$ was chosen as reactant due to its high availability and low cost. The reaction of dissolution in acidic medium is:

$$
\mathrm{Bi}_{2} \mathrm{O}_{3}+6 \mathrm{H}_{3} \mathrm{O}^{+} \longrightarrow 2 \mathrm{Bi}^{3+}+9 \mathrm{H}_{2} \mathrm{O}
$$

It means that at least 3 equivalents of $\mathrm{H}_{3} \mathrm{O}^{+}$per $\mathrm{Bi}$ atom are necessary to dissolve bismuth(III) oxide. 


\section{Table 1}

Solubility of $\mathrm{Bi}_{2} \mathrm{O}_{3}$ in acidic solutions

\begin{tabular}{llll}
\hline Aqueous solutions & \multicolumn{3}{c}{$\left[\mathrm{Bi}^{3+}\right] / \mathrm{mol} \mathrm{L}^{-1}$} \\
Nature & Concentration $/ \mathrm{mol} \mathrm{L}^{-1}$ & $\mathrm{pH}$ & \\
\hline $\mathrm{HNO}_{3}$ & 1 & 0 & $>0.1$ \\
$\mathrm{HNO}_{3}$ & 0.1 & 1 & $<0.02$ \\
$\mathrm{H}_{2} \mathrm{SO}_{4}$ & 0.5 & 0 & $<0.01$ \\
$\mathrm{H}_{2} \mathrm{SO}_{4}$ & 0.05 & 1 & $<0.01$ \\
$\mathrm{CH}_{3} \mathrm{COOH}$ & 1 & 2.4 & $<0.01$ \\
$\mathrm{CH}_{3} \mathrm{COOH} / \mathrm{CH}_{3} \mathrm{COO}^{-}$ & $0.5 / 0.5$ & 4.8 & $<0.01$ \\
\hline
\end{tabular}

$\mathrm{Bi}^{3+}$ is known to form a precipitate with the salts containing chloride and phosphate ions and so these media were not studied. The solubility of $\mathrm{Bi}_{2} \mathrm{O}_{3}$ in sulfuric acid is very low even at high concentration owing to the formation of a complex and they could not be solubilized at concentrations higher than $0.01 \mathrm{~mol} \mathrm{~L}^{-1}$ [40]. A solubility lower than $0.01 \mathrm{~mol} \mathrm{~L}^{-1}$ was also obtained with acetic acid. Only nitric acid was able to solubilize $\mathrm{Bi}_{2} \mathrm{O}_{3}$ at higher concentrations, which is consistent with the literature $[1,41,42]$. However, a strong acidic medium (concentrations higher than $0.1 \mathrm{~mol} \mathrm{~L}^{-1}$ ) was necessary to obtain a concentration of bismuth higher than $0.02 \mathrm{~mol} \mathrm{~L}^{-1}$. At this concentration, nitric acid which is a strong oxidizing agent is very aggressive and these conditions cannot be used for example for bismuth electrodeposition on metals.

To solubilize bismuth in less acidic medium, complexing agents such as tartaric acid [43], dimethylglyoxime [44], ethylene glycol [45], sodium citrate [46] and a mixture of ethylenediaminetetraacetic acid, 5-sulfosalicylic acid and potassium sodium tartrate [47] have been used. They allowed reaching bismuth concentrations up to $0.2 \mathrm{~mol} \mathrm{~L}^{-1}$ in basic medium. We also tried to solubilize $\mathrm{Bi}_{2} \mathrm{O}_{3}$ using different complexing agents (Table 2).

Table 2

Solubility of $\mathrm{Bi}_{2} \mathrm{O}_{3}$ using complexing agents

\begin{tabular}{|c|c|c|c|c|c|}
\hline \multicolumn{2}{|c|}{ Aqueous solutions } & \multirow{2}{*}{$\begin{array}{l}\text { Bismuth } \\
\text { solubility } \\
\text { / mol L-1 }\end{array}$} & \multicolumn{3}{|c|}{ Complexing agents $\mathrm{CA}$} \\
\hline Nature & $\mathrm{pH}$ & & Nature & $\begin{array}{l}\text { Concentration/ } \\
\text { mol L }^{-1}\end{array}$ & {$[\mathrm{CA}] /[\mathrm{Bi}]$} \\
\hline $\mathrm{CH}_{3} \mathrm{COOH}$ & 2.9 & 0.01 & Glucose & 0.2 & 20 \\
\hline $\mathrm{NaOH}$ & 13 & 0.01 & Citric acid & 0.5 & 50 \\
\hline $\mathrm{NaOH}$ & 13 & 0.01 & Succinic acid & 0.2 & 20 \\
\hline $\mathrm{NaOH}$ & 13 & 0.01 & Itaconic acid & 0.2 & 20 \\
\hline $\mathrm{NaOH}$ & 13 & 0.01 & Tartaric acid & 0.2 & 20 \\
\hline $\mathrm{NaOH}$ & 13 & 0.1 & Triethanolamine & 0.5 & 5 \\
\hline $\mathrm{NaOH}$ & 13 & 1 & Bis-Tris $^{a}$ & 1 & 1 \\
\hline
\end{tabular}

a 2,2-Bis(hydroxymethyl)-2,2',2'-nitrilotriethanol 
In acetic acid $(\mathrm{pH}=2.9)$, a high concentration of glucose allowed the solubilization of bismuth at a concentration of $10^{-2} \mathrm{~mol} \mathrm{~L} \mathrm{~L}^{-1}$. However, a slight increase of $\mathrm{pH}$ led to the formation of a precipitate. High concentrations of di and tricarboxylic acids were required to solubilize bismuth at $10^{-2} \mathrm{~mol} \mathrm{~L}^{-1}$ at $\mathrm{pH}$ 13. Concentrations 20 times higher than those of bismuth were used for the dicarboxylic acids and 50 times higher for citric acid. An interesting result is the high capacity of 2,2-Bis(hydroxymethyl)-2,2',2'-nitrilotriethanol (Bis-Tris) to solubilize bismuth in strong basic medium. A concentration up to $1 \mathrm{~mol} \mathrm{~L}^{-1}$ was obtained when 1 equivalent of Bis-Tris were added to $\mathrm{Bi}_{2} \mathrm{O}_{3}$, showing that the formed complex was very soluble at $\mathrm{pH} 13$.

\subsection{Cyclic voltammetry analysis}

A solution of $\mathrm{Bi}_{2} \mathrm{O}_{3}$ at 1 mol L${ }^{-1}$ with 1.1 equivalents of Bis-Tris at pH 14 was analyzed by cyclic voltammetry. The reduction of the Bi(III) complex into metallic bismuth appeared at -1.4 V/SCE (Figure 3).

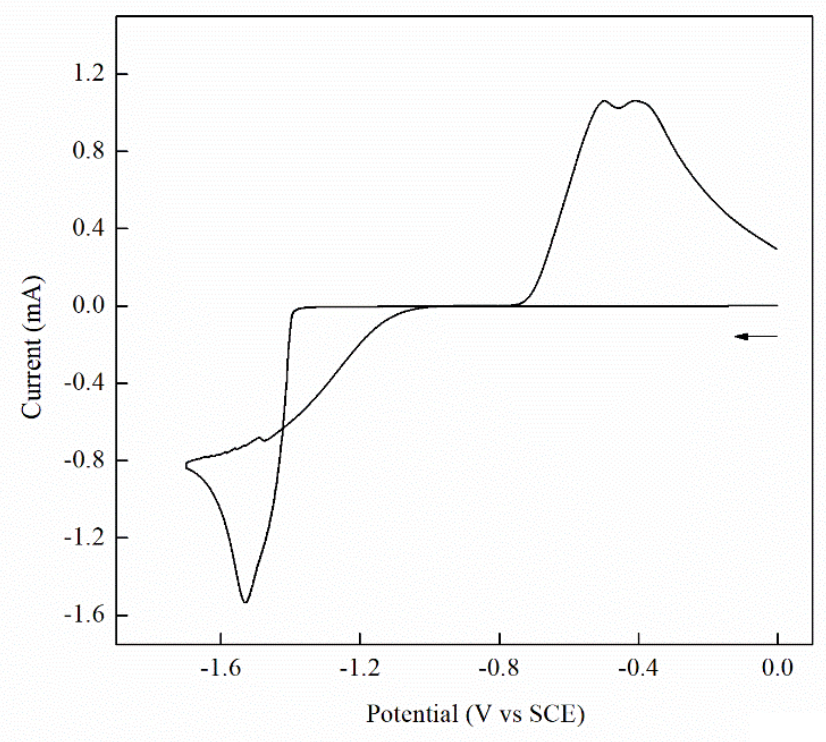

Fig. 3. Cyclic voltammogram obtained at a glassy carbon electrode $\left(S=7 \mathrm{~mm}^{2}\right)$ of a solution of $\mathrm{Bi}_{2} \mathrm{O}_{3}$ solubilized at $1 \mathrm{~mol} \mathrm{~L}^{-1}$ by 1.1 equivalents of Bis-Tris at $\mathrm{pH} 14$. Scan rate $100 \mathrm{mV} \mathrm{s}^{-1}$

The decrease of the current was slower when the potential was more negative than $-1.4 \mathrm{~V} / \mathrm{SCE}$ corresponding to the diffusion limit of the complex to the electrode surface. The curve displayed a characteristic intersection showing the electrodeposition of metallic bismuth on the electrode surface and a well-defined profile of a reversible redox process characterized by the presence of cathodic and anodic peaks for $\mathrm{Bi}^{3+} / \mathrm{Bi}$ system. This electrochemical analysis showed that the electrolytic medium is convenient to achieve bismuth electrodeposition on glassy carbon electrodes. Therefore, this electrodeposition solution was chosen for further bismuth electroplating experiments. 


\subsection{Electrodeposition of bismuth}

The parameters used for the electrodeposition on 3D materials are different from those used for plane surfaces for which high concentrations of metal salts are usually employed to enhance the current efficiency. Indeed, in a 3D electrode, the potential is not homogeneous on all the surface of the fibers, being higher at the external surface of the material and lower inside. We have previously shown that the electrodeposition of metals on porous 3D electrodes requires a low concentration of metal salts (around 10-2 mol L-1) and a high volume current density (around 100-200 $\mathrm{mA} \mathrm{cm}^{-3}$ ) allowing the electrodeposition process to be quickly limited by the diffusion on the external surface of the material, whereas the process still occurs inside where the potential is lower $[36,37]$.

To improve the repartition of the potential and increase the mass transfer inside the $3 \mathrm{D}$ electrode, a home-made electrochemical flow cell was used [38]. Moreover, a periodically changing current with short on-pulse and longer off-pulse was applied to favor the diffusion of species to the electrode surface. The $\mathrm{pH}$ and the concentration of bismuth were adjusted to the initial one after each electrodeposition step. The modified electrodes were analyzed by SEM. The main results are summarized in Table 3 and Figure 4.

\section{Table 3}

Optimization of the electrodeposition parameters (graphite felt cuboid : $11 \times 6 \mathrm{~cm}, 3 \mathrm{~mm}$ thickness).

\begin{tabular}{|c|c|c|c|c|c|c|c|}
\hline Entry & $\begin{array}{l}{[\mathrm{Bi}(\mathrm{III})]} \\
/ \mathrm{mole} \\
\mathrm{L}^{-1}\end{array}$ & $\begin{array}{l}\mathrm{t}_{\mathrm{on}} / \\
\mathrm{s}\end{array}$ & $\begin{array}{l}\mathrm{t}_{\text {off }} / \\
\mathrm{s}\end{array}$ & 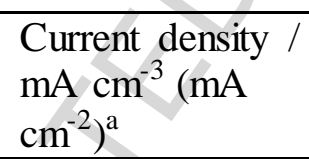 & $\begin{array}{l}\text { Flow } \\
\text { rate } / \mathrm{mL} \\
\min ^{-1}\end{array}$ & Cycles $^{b}$ & $\begin{array}{l}\text { Electrode } \\
\text { appearance }\end{array}$ \\
\hline 1 & $10^{-2}$ & 30 & 30 & $250(4.3)$ & 20 & 10 & $\begin{array}{l}\text { - A lot of powder } \\
\text { - Little coating }\end{array}$ \\
\hline 2 & $5 \times 10^{-3}$ & 0.5 & & $(2.6)$ & 20 & 10 & $\begin{array}{l}\text { - No powder } \\
\text { - Good coating on the } \\
\text { external surface } \\
\text { - Little coating inside } \\
\text { the electrode }\end{array}$ \\
\hline 3 & $5 \times 10^{-3}$ & 0.5 & 10 & $250(4.3)$ & 20 & 3.5 & $\begin{array}{l}\text { - No powder } \\
\text { - Good external and } \\
\text { internal coating but } \\
\text { some parts without } \\
\text { coating }\end{array}$ \\
\hline 4 & $5 \times 10^{-3}$ & 1 & 5 & $250(4.3)$ & 25 & 3 & $\begin{array}{l}\text { - Bi dendrites } \\
\text { - Good external and } \\
\text { internal coating }\end{array}$ \\
\hline 5 & $5 \times 10^{-3}$ & 1 & 5 & $250(4.3)$ & 50 & 3 & $\begin{array}{l}\text { - Bi dendrites } \\
\text { - Good external and } \\
\text { internal coating }\end{array}$ \\
\hline 6 & $5 \times 10^{-3}$ & 1 & 10 & $250(4.3)$ & 50 & 3.5 & $\begin{array}{l}\text { - Homogenous Bi layer, } \\
\text { but some parts without }\end{array}$ \\
\hline
\end{tabular}




$\begin{array}{llllllll}7 & 5 \times 10^{-3} & 1 & 15 & 250(4.3) & 50 & 4 & \text { - Homogenous Bi layer }\end{array}$

${ }^{\mathrm{b}}$ Surface current densities were calculated according to a previous estimation of the active surface area $\left(58 \mathrm{~cm}^{2} \mathrm{~cm}^{-3}\right)$ of the graphite felt [48] ${ }^{\mathrm{a}}$ A cycle is defined as a pass through the graphite felt in one direction and another pass in the opposite direction.

The first attempts made with a concentration of bismuth of $10^{-2} \mathrm{~mol} \mathrm{~L} \mathrm{~L}^{-1}$ and a volume current intensity of $250 \mathrm{~mA} \mathrm{~cm}$ (entry 1) led to the formation of a black powder identified as metallic bismuth in the electrochemical cell. The decrease of the bismuth concentration and current density did not improve the electrodeposition process. It has been previously shown that short anodic pulses result in an increased nucleation rate, leading to the formation of finer grains [44]. Thus, we decreased the on-pulse time to $0.5 \mathrm{~s}$, upon varying the current density from 50 to $250 \mathrm{~mA}$ $\mathrm{cm}^{-3}$. When low current densities were used, the formation of powder still occurred. The powder began to disappear for current densities higher than $150 \mathrm{~mA} \mathrm{~cm}^{-3}$ (entry 2). Only high current densities (entry 3) allowed a good coating inside the graphite felt although some fibers were not totally covered by bismuth. To improve the coating, the time of the on-pulse was set at $1 \mathrm{~s}$, keeping the current density at $250 \mathrm{~mA} \mathrm{~cm}^{-3}$ (entry 4). A good coating of around $6 \mu \mathrm{m}$ was observed on both external and internal parts of the graphite felt. However, the presence of dentritic excrescences (Figure $4 \mathrm{a}$ and $\mathrm{b}$ ) made the electrode material fragile and mechanically not stable, even if the presence of powder was not observed in the cell. To prevent the formation of dendrites, the flow rate (entry 5) and off-pulse time (entry 6 and 7) were increased. The aim was to maintain a concentration of bismuth more constant inside the felt during the electrodeposition step. The formation of dendrites disappeared with higher flow rate and increased off-pulse time, leading to a stable thin layer of bismuth (around 0.5 to $1 \mu \mathrm{m}$ ) (Figure $4 \mathrm{c}$ and e). Bi deposit has a granular aspect consisting of different sizes crystallites assembled and attached very strongly on the surface of graphite fibers (Figure 5). Changing the off-pulse time from 10 to $15 \mathrm{~s}$ still improved the homogeneity of the coating inside the felt (Figure $4 \mathrm{~d}$ and $\mathrm{f}$ ). 

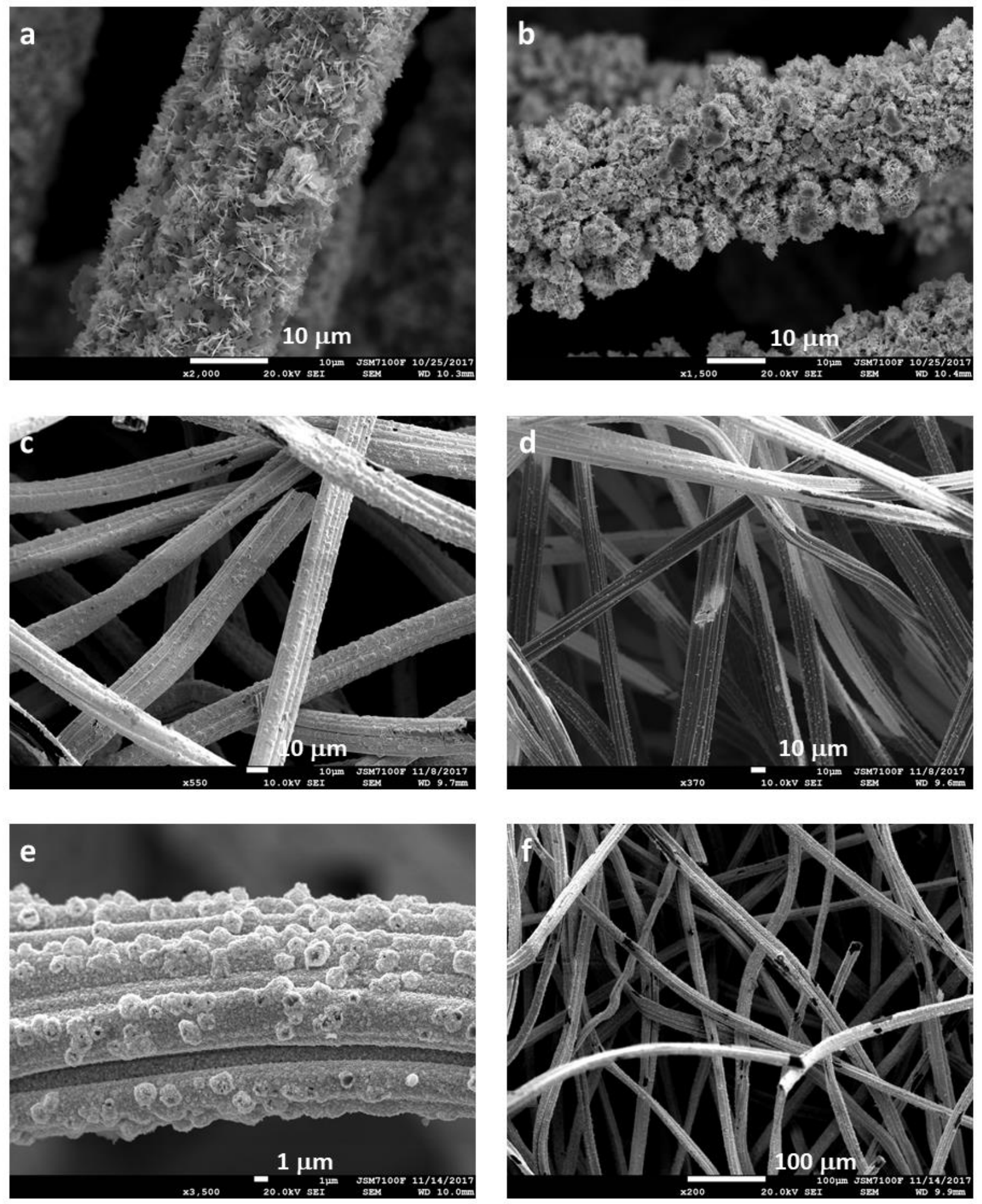

Fig. 4. SEM images of $\mathrm{Bi}$ modified graphite felt prepared according to experimental conditions given in Table 3. a) entry 4 (inside) b) entry 4 (external surface) c) and d) entry 6 (inside) e) f) entry 7 (inside). 


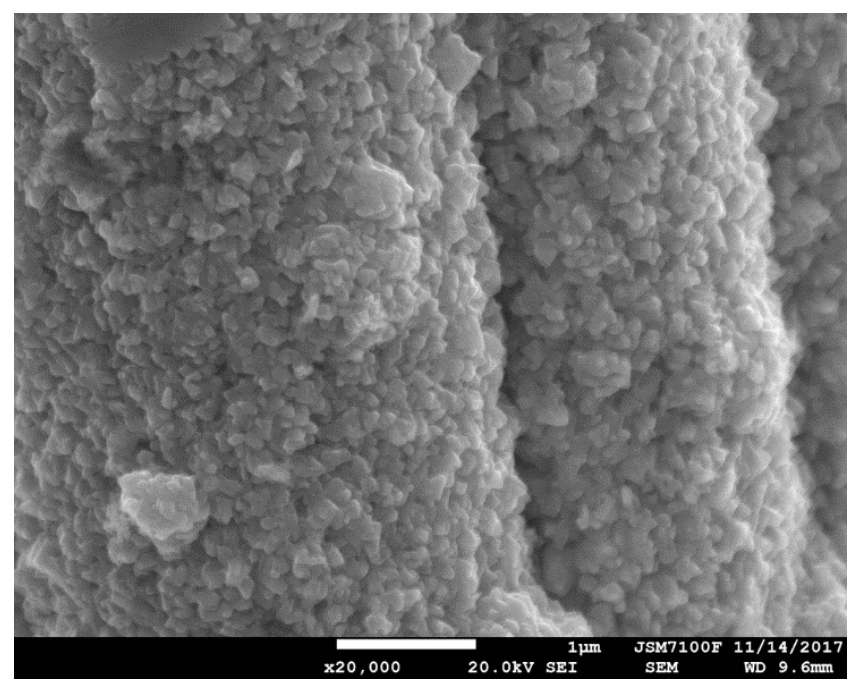

Fig. 5. SEM images of $\mathrm{Bi}$ modified graphite felt prepared according to experimental conditions given in Table 3 (entry 7, inside).

The Bi loading was calculated by the difference of weight before and after electrodeposition of Bi. A value of $0.10 \pm 0.01 \mathrm{~g} \mathrm{~cm}^{-3}$ was estimated for electrodeposition performed under the best conditions (Table 3, entry 7). This low Bi coating provides a bismuth electrode material with a low bulk density of $0.181 \pm 0.007 \mathrm{~g} \mathrm{~cm}^{-3}$. A surface Bi loading of $1.7 \mathrm{mg} \mathrm{cm} \mathrm{cm}^{-2}$ can be calculated from the active surface area $\left(58 \mathrm{~cm}^{2} \mathrm{~cm}^{-3}\right)$ previously estimated for the graphite felt [48]. From this value and the density of bismuth $\left(9.78 \mathrm{~g} \mathrm{~cm}^{-3}\right)$ a mean thickness of $1.7 \mu \mathrm{m}$ was calculated for the bismuth layer. This value is a slightly higher than thicknesses measured by SEM (from 0.5 to $1 \mu \mathrm{m}$ depending on the graphite fiber), probably due to an underestimation of the active surface area of the graphite felt. The current efficiency (CE) of the electrodeposition process was calculated according to the following equation:

$$
C E=\frac{Q_{t h}}{Q_{\text {exp }}}=\frac{n_{B i} \times 96500 \times n_{e}}{I \times t}
$$

with $Q_{t h}$ and $Q_{e x p}$ the theoretical and experimental charges, respectively, $n_{B i}$ the number of moles of deposited $\mathrm{Bi}, n_{e}$ the number of electrons, $I$ the applied current $(5 \mathrm{~A})$ and $t$ the time corresponding to the applied current (sum of $t_{\text {on }}$ ).

A current efficiency of $53 \%$ was obtained. This fairly low value can be expected for this electrodeposition process involving a low concentration of bismuth and a high applied current to assure a homogenous coating of the graphite fibers. Indeed, the amount of bismuth rapidly decreased at the vicinity of the fibers favoring the hydrogen evolution reaction.

The specific surface area $\left(\mathrm{S}_{\mathrm{BET}}\right)$ of the Bi modified electrode prepared under the best conditions was estimated to be $0.40 \pm 0.03 \mathrm{~m}^{2} \mathrm{~g}^{-1}$ by BET measurements. The isotherm plot of Bi-modified graphite felt, shown in Figure 6, is close to type IV with a small hysteresis loop in the 0.8-1.0 relative pressure range typical of a mesoporous structure. Moreover, the absence of a plateau at high 
$\mathrm{P} / \mathrm{P}^{0}$ indicates that the pore size distribution extends to the macropore range. The average diameter of pores, supposedly of cylindrical shape, estimated from $\mathrm{S}_{\mathrm{BET}}$, is $86.8 \pm 0.3 \AA$. The estimated specific surface area is on the same order of magnitude as that of the graphite felt that is around 0.7 $\mathrm{m}^{2} \mathrm{~g}^{-1}$.

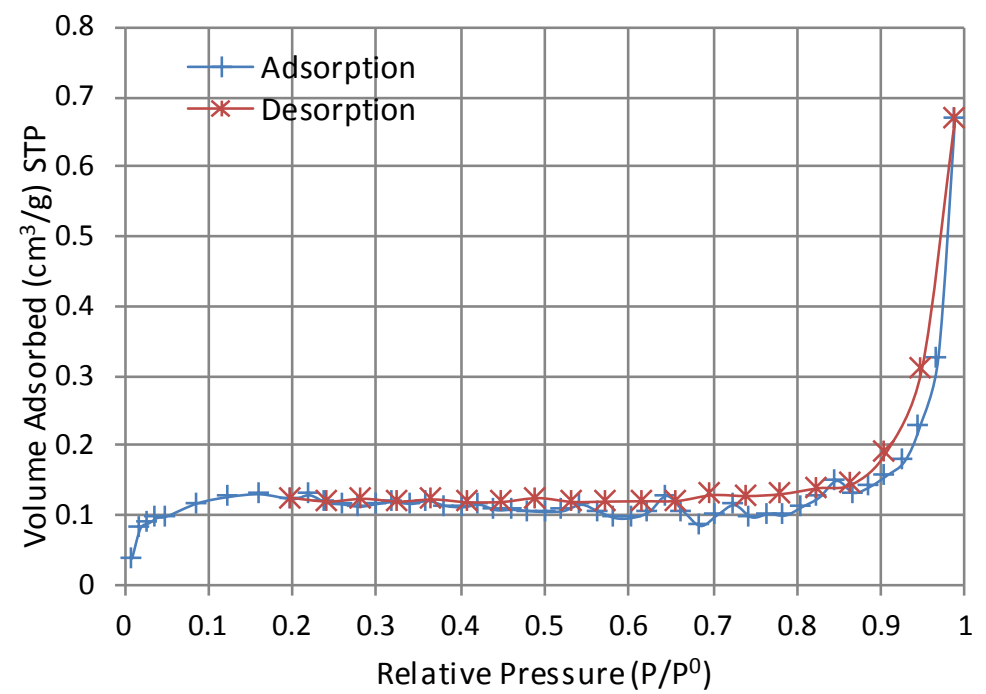

Fig. 6. Example of nitrogen adsorption-desorption isotherm obtained at $77 \mathrm{~K}$ for the Bi-modified graphite felt.

\section{Conclusions}

In conclusion, we showed that bismuth can be solubilized at high concentration up to $1 \mathrm{~mol} \mathrm{~L}^{-1}$ in basic medium with the use of Bis-Tris as a suitable complexing agent. This medium is particularly interesting to electrodeposit bismuth on substrates that are sensitive to strong acidic medium such as metallic electrodes. We took advantages of this medium to achieve a Bi-modified graphite felt. The following parameters were essential to assure homogeneous coating of the fibers and avoid the formation of dendrites that led to fragile electrode material: i) a favourable cell geometry with the working electrode facing two counter electrodes to have a better repartition of the potential inside the $3 \mathrm{D}$ material ii) a pulsed current program with short on-pulses and long off-pulses to favor the diffusion of species to the electrode surface iii) a substantial flow rate of the electrolytic solution warranting that on-pulses are applied to the electrode perfused by a renewed deposition solution iv) a relatively low concentration of bismuth $\left(5 \times 10^{-3} \mathrm{~mol} \mathrm{~L}^{-1}\right)$ to rapidly reach the diffusion limit on the external surface of the material and favor electrodeposition inside the felt where the potential is lower. This material presenting a high specific surface area with a low bulk density is particularly interesting for electrocatalytic applications.

\section{Acknowledgments}

The first authors are thankful to The Lebanese Social Association Azm and Saadeh, Doctoral school (Science de la Matière (SDLM)) and the CNRS for the financial support during this $\mathrm{PhD}$ thesis work. 


\section{References}

[1] E. Sandnes, M.E. Williams, U. Bertocci, M.D. Vaudin, G.R. Stafford, Electrodeposition of bismuth from nitric acid electrolyte, Electrochimica Acta. 52 (2007) 6221-6228.

[2] M. Yang, Z. Hu, Electrodeposition of bismuth onto glassy carbon electrodes from nitrate solutions, J. Electroanal. Chem. 583 (2005) 46-55.

[3] F. Arduini, J.Q. Calvo, G. Palleschi, D. Moscone, A. Amine, Bismuth-modified electrodes for lead detection, TrAC Trends Anal. Chem. 29 (2010) 1295-1304.

[4] R.T. Kachoosangi, C.E. Banks, X. Ji, R.G. Compton, Electroanalytical determination of cadmium (II) and lead (II) using an in-situ bismuth film modified edge plane pyrolytic graphite electrode, Anal. Sci. 23 (2007) 283-289.

[5] X.-Y. Liu, P. Sun, S. Ren, L.-S. Wen, Electrodeposition of high-pressure-stable bcc phase bismuth flowerlike micro/nanocomposite architectures at room temperature without surfactant, Electrochem. Commun. 10 (2008) 136-140.

[6] A.P. De Souza, M.O. Salles, E.S. Braga, M. Bertotti, Determination of Dissolved Zn (II) and Cd (II) in Estuarine Water by Using a Bismuth Film Microelectrode, Electroanalysis. 23 (2011) 2511-2515.

[7] I. IvS vancara, C. Prior, S.B. Holvcevar, J. Wang, A Decade with Bismuth-Based Electrodes in Electroanalysis, Electroanalysis. 22 (2010) 1405-1420.

[8] B. Nigović, B. Šimunić, S. Hocevar, Voltammetric measurements of aminosalicylate drugs using bismuth film electrode, Electrochimica Acta. 54 (2009) 5678-5683.

[9] L.C.S. de Figueiredo-Filho, V.B. dos Santos, B.C. Janegitz, T.B. Guerreiro, O. Fatibello-Filho, R.C. Faria, L.H. Marcolino-Junior, Differential Pulse Voltammetric Determination of Paraquat Using a Bismuth-Film Electrode, Electroanalysis. 22 (2010) 1260-1266.

[10] M. Moreno, E. Bermejo, M. Chicharro, A. Zapardiel, A.S. Arribas, Cathodic electrochemical determination of herbicides in acid media using a bismuth film electrode, Electroanalysis. 21 (2009) 415-421.

[11] E.A. Hutton, B. Ogorevc, S.B. Hočevar, F. Weldon, M.R. Smyth, J. Wang, An introduction to bismuth film electrode for use in cathodic electrochemical detection, Electrochem. Commun. 3 (2001) 707-711.

[12] V. Urbanová, M. Bartolvs, K. Vytlvras, A. Kuhn, Porous bismuth film electrodes for signal increase in anodic stripping voltammetry, Electroanalysis. 22 (2010) 1524-1530.

[13] K. Takamura, H. Shimamura, N. Koshiba, Thin film for package of alkaline battery and thin air battery using the same, App. 10/581,113, 2005.

[14] B.N. Popov, G. Zheng, R.E. White, Electroplating of thin films of bismuth onto type 4340 steel and alloy 718 to prevent hydrogen embrittlement, Corrosion. 51 (1995) 429-435. 
[15] J.L. DiMeglio, J. Rosenthal, Selective conversion of CO2 to CO with high efficiency using an inexpensive bismuth-based electrocatalyst, J. Am. Chem. Soc. 135 (2013) 8798-8801.

[16] J. Medina-Ramos, J.L. DiMeglio, J. Rosenthal, Efficient reduction of CO2 to CO with high current density using in situ or ex situ prepared Bi-based materials, J. Am. Chem. Soc. 136 (2014) 8361-8367.

[17] S. He, F. Ni, Y. Ji, L. Wang, Y. Wen, H. Bai, G. Liu, Y. Zhang, Y. Li, B. Zhang, The pOrbital Delocalization of Main-Group Metals to Boost CO2 Electroreduction, Angew. Chem. 57 (2018) 16114-16119.

[18] M. Park, J. Ryu, J. Cho, Nanostructured electrocatalysts for all-vanadium redox flow batteries, Chem. Asian J. 10 (2015) 2096-2110.

[19] S. Jiang, Y.-H. Huang, F. Luo, N. Du, C.-H. Yan, Synthesis of bismuth with various morphologies by electrodeposition, Inorg. Chem. Commun. 6 (2003) 781-785.

[20] X. Duan, J. Yang, W. Zhu, X. Fan, C. Xiao, Structure and electrical properties of bismuth thin films prepared by flash evaporation method, Mater. Lett. 61 (2007) 4341-4343.

[21] S. Cho, Y. Kim, A.J. Freeman, G.K.L. Wong, J.B. Ketterson, L.J. Olafsen, I. Vurgaftman, J.R. Meyer, C.A. Hoffman, Large magnetoresistance in postannealed Bi thin films, Appl. Phys. Lett. 79 (2001) 3651-3653.

[22] D.E. Beutler, N. Giordano, Localization and electron-electron interaction effects in thin Bi wires and films, Phys. Rev. B. 38 (1988) 8.

[23] D.-H. Kim, S.-H. Lee, J.-K. Kim, G.-H. Lee, Structure and electrical transport properties of bismuth thin films prepared by RF magnetron sputtering, Appl. Surf. Sci. 252 (2006) 35253531.

[24] Y.-D. Tsai, C.-C. Hu, C.-C. Lin, Electrodeposition of Sn-Bi lead-free solders: Effects of complex agents on the composition, adhesion, and dendrite formation, Electrochem. Acta 53 (2007) 2040-2047.

[25] Y.-D. Tsai, C.-C. Hu, Composition control of Sn-Bi deposits: interactive effects of citric acid, ethylenediaminetetraacetic acid, and poly (ethylene glycol), J. Electrochem. Soc. 156 (2009) D490-D496.

[26] I. Svancara, M. Fairouz, K. Ismail, R. Metlka, K. Vytras, A contribution to the characterisation of mercury-and bismuth film carbon paste electrodes in stripping voltammetry, Sci. Pap. Univ. Pardubice Ser. Fac. Chem. Technol. 9 (2003) 31-47.

[27] A. Królicka, R. Pauliukait=, I. S̆ vancara, R. Metelka, A. Bobrowski, E. Norkus, K. Kalcher, K. Vytřas, Bismuth-film-plated carbon paste electrodes, Electrochem. Commun. 4 (2002) 193-196. 
[28] G. Kefala, A. Economou, A. Voulgaropoulos, M. Sofoniou, A study of bismuth-film electrodes for the detection of trace metals by anodic stripping voltammetry and their application to the determination of $\mathrm{Pb}$ and $\mathrm{Zn}$ in tapwater and human hair, Talanta. 61 (2003) 603-610.

[29] J. Wang, J. Lu, Ü.A. Kirgöz, S.B. Hocevar, B. Ogorevc, Insights into the anodic stripping voltammetric behavior of bismuth film electrodes, Anal. Chim. Acta. 434 (2001) 29-34.

[30] J. Wang, J. Lu, S.B. Hocevar, P.A.M. Farias, B. Ogorevc, Bismuth-coated carbon electrodes for anodic stripping voltammetry, Anal. Chem. 72 (2000) 3218-3222.

[31] J. Wang, J. Lu, S.B. Hocevar, B. Ogorevc, Bismuth-coated screen-printed electrodes for stripping voltammetric measurements of trace lead, Electroanalysis. 13 (2001) 13-16.

[32] D. Demetriades, A. Economou, A. Voulgaropoulos, A study of pencil-lead bismuth-film electrodes for the determination of trace metals by anodic stripping voltammetry, Anal. Chim. Acta. 519 (2004) 167-172.

[33] A. Economou, Bismuth-film electrodes: recent developments and potentialities for electroanalysis, TrAC Trends Anal. Chem. 24 (2005) 334-340.

[34] T. Romann, E. Lust, Electrochemical properties of porous bismuth electrodes, Electrochimica Acta. 55 (2010) 5746-5752.

[35] A. Storck, M.A. Enriquez-Granados, M. Roger, F. Coeuret, The behaviour of porous electrodes in a flow-by regime-I. theoretical study, Electrochimica Acta. 27 (1982) 293-301.

[36] D. Floner, F. Geneste, Homogeneous coating of graphite felt by nickel electrodeposition to achieve light nickel felts with high surface area, Electrochem. Commun. 9 (2007) 2271-2275.

[37] G. Chamoulaud, D. Floner, C. Moinet, C. Lamy, E.M. Belgsir, Biomass conversion II: simultaneous electrosyntheses of furoic acid and furfuryl alcohol on modified graphite felt electrodes, Electrochimica Acta. 46 (2001) 2757-2760.

[38] R. Abdallah, F. Geneste, T. Labasque, H. Djelal, F. Fourcade, A. Amrane, S. Taha, D. Floner, Selective and quantitative nitrate electroreduction to ammonium using a porous copper electrode in an electrochemical flow cell, J. Electroanal. Chem. 727 (2014) 148-153.

[39] C. Moinet, Electrosynthèse organique en continu. Méthodes directes et indirectes, J. Phys. IV. 4 (1994) C1-175.

[40] G.-U. Flechsig, M. Kienbaum, P. Gründler, Ex situ atomic force microscopy of bismuth film deposition at carbon paste electrodes, Electrochem. Commun. 7 (2005) 1091-1097.

[41] S. Michel, S. Diliberto, C. Boulanger, N. Stein, J.M. Lecuire, Galvanostatic and potentiostatic deposition of bismuth telluride films from nitric acid solution: effect of chemical and electrochemical parameters, J. Cryst. Growth. 277 (2005) 274-283. 
[42] C.H. Chang, Y. Rheem, Y.-H. Choa, D.H. Shin, D.-Y. Park, N.V. Myung, Bi and Te thin films synthesized by galvanic displacement from acidic nitric baths, Electrochimica Acta. 55 (2010) $743-752$.

[43] A. Helfen, S. Merkourakis, G. Wang, M.G. Walls, E. Roy, K. Yu-Zhang, Y. Leprince-Wang, Structure and stability studies of electrodeposited $\delta$-Bi2O3, Solid State Ion. 176 (2005) 629633.

[44] S. Legeai, S. Bois, O. Vittori, A copper bismuth film electrode for adsorptive cathodic stripping analysis of trace nickel using square wave voltammetry, J. Electroanal. Chem. 591 (2006) 93-98.

[45] C.-C. Huang, T.-Y. Wen, K.-Z. Fung, Orientation-controlled phase transformation of Bi2O3 during oxidation of electrodeposited Bi film, Mater. Res. Bull. 41 (2006) 110-118.

[46] L.M. Nunes, R.C. Faria, The influence of the electrodeposition conditions on the electroanalytical performance of the bismuth film electrode for lead determination, Electroanal. Int. J. Devoted Fundam. Pract. Asp. Electroanal. 20 (2008) 2259-2263.

[47] L. Zhou, Y. Dai, H. Zhang, Y. Jia, J. Zhang, C. Li, Nucleation and growth of bismuth electrodeposition from alkaline electrolyte, Bull. Korean Chem. Soc. 33 (2012) 1541-1546.

[48] J.-M. Fontmorin, F. Fourcade, F. Geneste, I. Soutrel, D. Floner, A. Amrane, C. R. Chimie 18 (2015) 32-38. 

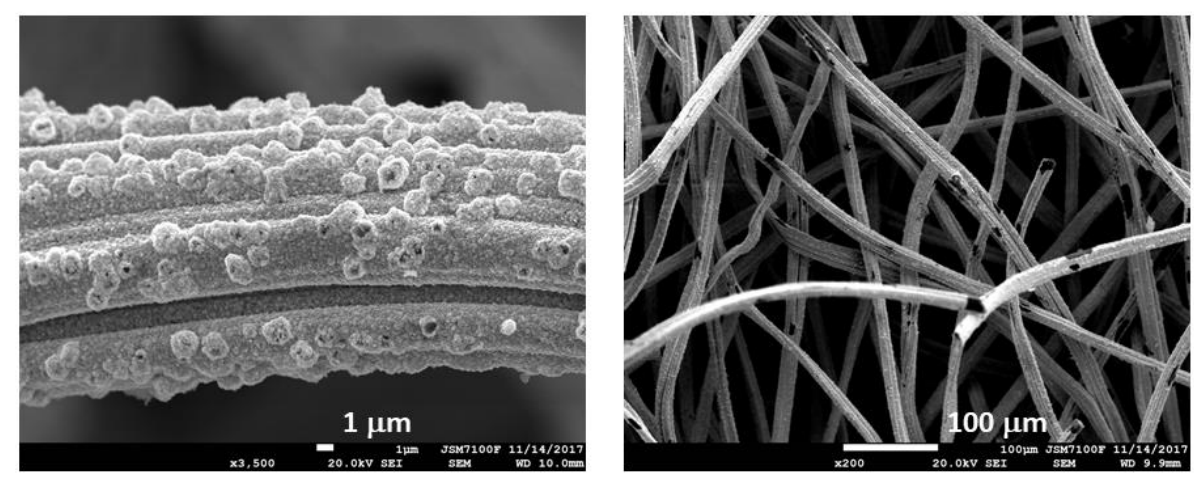

Graphical abstract 


\section{Highlights}

- A solubility up to $1 \mathrm{~mol} \mathrm{~L}^{-1}$ of bismuth was obtained in basic medium using Bis-Tris

- Electrodeposition of bismuth on graphite felt with homogeneous coating of fibers.

- The formation of dendrites that led to mechanically fragile material was limited.

- The material has a high surface area and a low bulk density. 